UDC 637.56 81.05

COBISS.SR-ID 250159372

Original research paper

Acta Agriculturae Serbica, Vol. XXII, 43 (2017); 47-55

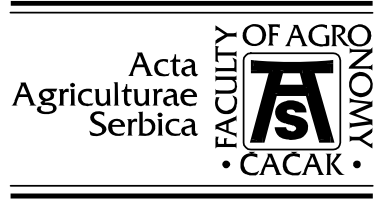

\title{
Basic parameters of the quality of fresh meat of different types of freshwater fish
}

\author{
Vladimir Kurćubić ${ }^{*}$, Goran Marković ${ }^{1}$, Pavle Mašković ${ }^{1}$, Nemanja Miletić ${ }^{1}$, \\ Dušan Vučićević ${ }^{1}$ \\ ${ }^{1}$ University of Kragujevac, Faculty of Agronomy, Cara Dusana 34, 32000 \\ Čačak, Republic of Serbia \\ Corresponding author: vkurcubic@kg.ac.rs
}

\begin{abstract}
The goal of this current study is to compare the chemical composition of fresh meat of different types of freshwater fish used in the diet of consumers. Comparison of basic chemical parameters of meat quality of cultivated and fish species from open waters was made. Most of the chemical composition parameters are very little differs from the values for the same parameters for most of the investigated fish species, which are available in the literature data. The results of this, as well as a number of other studies, confirm that fish from open waters have a generally higher content of water and lower fat content, while fish from breeding is characterized by lower water content and higher fat content. The highest protein content was found in fresh meat of the tiny carp (20.92\%), and the lowest value $(17.01 \%)$ determined for the protein content in meat of the bleak. The highest fat content was found in the flesh of the tiny carp $(11.53 \%)$, which is a consequence of genetic characteristics and intensive feeding in fishery conditions. The lowest fat content was determined in the sample of fresh meat of the bleak, amounting to $3.64 \%$. The highest value of the ash content is determined in the schneider meat, which is $1.96 \%$, the lowest in the meat of the tiny carp $(0.82 \%)$. Fish from open waters have higher ash content as a result of life in ecosystems that contain larger amounts of limestone and other minerals.
\end{abstract}

Key words: freshwater fish, raw meat, chemical composition. 


\section{Introduction}

Nutritional and health significance of fish meat is the main reason for the continuous growth of demand for fish in the world market, especially those from aquaculture (Burger and Gochfeld, 2009). Nutrition with fish meets satisfies the needs of human organism for high quality proteins, free amino acids, minerals, vitamins (Ackman, 2000) and polysaturated fatty acids - PUFA (Kmínková et al., 2001). Particularly important are n-3 PUFAs, because they can not be synthesized by human organism, so they have to be fed with food (Alasalvar et al., 2002). Some of the n-3 PUFAs are effectively synthesized only in aquatic organisms, so it is desirable that people consume marine or freshwater fish (Sushchik et al., 2007). Nutritional requirements of fish for growth, reproduction and normal physiological functions are similar to those of other animals (Ćirković et al., 2005). Fish have high nutritional requirements for dietary proteins (Đorđević et al., 2005), so the efficacy of protein use and utilization is significantly more important in fish nutrition than other animal species. The chemical composition of fish meat varies from one species to another, and even within the same species. Although the values of the parameters of the chemical composition of fish meat may show a significant variation, the minimum and maximum values are extreme, and are rarely observed (Silva and Chamul, 2000; Žlender, 2000). The chemical composition of fresh meat of fish from open waters significantly variable in relation to cultivated fish (Love, 1988). High water content (up to $80 \%$ ) and high water activity $\left(a_{\mathrm{w}}\right.$-value) make the meat of fish the ideal substrate for the development of microorganisms, and consequently represents one of the foods that easily spoiling (Aberoumand, 2010; Gandotra et al.; 2012, Begum et al., 2013). The content of proteins, essential amino acids and fats is, on average, significantly higher in meat of fish grown in aquaculture (Lovell and Mohammed, 1989). The protein content in meat of different fish species ranges from $12 \%$ to $24 \%$ (Huss, 1995).

The amount of fat in fish meat varies from $0.7 \%$ to $20 \%$, and in some cases even more. Fats of fish differ from the fat of warm-blooded animals and by chemical composition. About $40 \%$ of fish oil is composed of long chains (14-22 $\mathrm{C}$ atoms). Fish fat is largely composed of unsaturated fatty acids (60-84\%). In the marine fish, highly unsaturated fatty acids with 5 or 6 double bonds constitute about 88\% fat content (Stansby and Hall, 1967). Fat content in fish meat increases with increasing fish size and growth rate, factors that are primarily influenced by nutrition. The fat content is inversely proportional to the water content (Kaushik, 1995). Mineral substances in fish meat are in the form of salt (mostly in the form of salts of potassium, sodium, calcium, magnesium and phosphorus). Meat of fish is rich in iron, copper, iodine, chromium, zinc and fluorine (Konosu and Yamaguchi, 1982). 
The main aim of the research in this paper was to compare the chemical composition of fresh meat of different types of freshwater fish used in the diet of consumers. Comparison of basic chemical parameters of meat quality of cultivated and fish species from open waters was made.

\section{Materials and methods}

Materials for testing the chemical composition were samples of freshwater fish originating from fishponds, which were commercially procured: carp, tiny carp and rainbow trout. The other investigated fish species (Prussian carp, bleak and schneider) were purchased from open waters.

Tests were carried out on fresh fish samples. Sampling was performed by cutting fish (certain fish species) along the back feather, and by cutting the appropriate amount of meat. Once the meat is released from the bones, it is homogenized in the avian with a fist. The procedure was repeated for each sample of the fish species tested.

The determination of moisture content by drying, content of mineral matter ash by burning method, fat content by the Soxlet method and the content of nitrogen and total proteins by Kjeldahl method was performed. Analytical tests were performed in the laboratory of the Faculty of Agronomy in Čačak.

\section{Results and Discussion}

The obtained results of the chemical composition of fresh meat of different fish species are shown in Table 1.

Based on the experimental results presented (Table 1), it can be concluded that there are differences in the values of the selected parameters of the chemical composition of fresh meat of the tested freshwater fish species.

The highest moisture content is determined in the bleak meat and amounts to $76.47 \%$. The lowest moisture content of $66.40 \%$ was recorded in the tiny carp meat. The moisture content of the carp meat (76.13\%) is approximate to the test values found for a moisture content of $78.31 \pm 1.09 \%$ in the carp meat originating from the Ečka fishpond (Ljubojević et al., 2013). The same authors determined the value of moisture content $(70.32 \pm 1.00 \%)$ in carp flesh originating from the cage system of rearing in the Vrbas fishpond. This value is higher than the moisture content in fresh meat of the tiny carp, determined by our work $(66.40 \%)$. The moisture content of $75.67 \%$ in the rainbow trout meat determined by this paper is slightly lower than the water content $(77.03 \%)$ which determined Bud et al. (2008). Celik et al. (2008) also found lower water content (71.65\%) in the rainbow trout meat. In the analyzed of the Prussian carp meat, moisture content of $72.22 \%$ was determined. This value is lower than the moisture content $(76.24 \pm 0.39 \%)$ found for this species by İzci (2010), and values (76.24 \pm $0.31 \%)$ determined by Ozyilmaz et al. (2016). The value $(73.13 \pm 0.25 \%)$ of the 
approximate value obtained in this paper is recorded by Mahdi et al. (2006). The moisture content of the bleak meat was $76.47 \%$, with $75.76 \%$ in the schneider meat. Both values are in accordance with values $(76.57 \pm 0.13 \%$ and $76.6 \pm$ $1.1 \%$ ), which are reported by other authors for moisture content in the related fish species Alburnus mossulensis (Mahdi et al., 2006; Duman and Peksezer, 2016).

Table 1. Values of chemical composition parameters of meat of different fish species

\begin{tabular}{|l|c|c|c|c|c|c|}
\hline \multicolumn{7}{|c|}{ Fish species tested } \\
\hline $\begin{array}{l}\text { Determined } \\
\text { chemical } \\
\text { parameters }\end{array}$ & $\begin{array}{c}\text { Carp } \\
\text { carp } \\
\text { (Cyprinus } \\
\text { carpio L.) }\end{array}$ & $\begin{array}{c}\text { Rainbow } \\
\text { trout } \\
\text { (Cyprinus } \\
\text { carpio L. })\end{array}$ & $\begin{array}{c}\text { Prussian } \\
\text { carp } \\
(\text { Oncorhynchus } \\
\text { mykiss })\end{array}$ & $\begin{array}{c}\text { Bleak } \\
\text { (Carassiys } \\
\text { gibelio) }\end{array}$ & $\begin{array}{c}\text { (Alburnus } \\
\text { alburnus })\end{array}$ & $\begin{array}{c}\text { (Alburnoides } \\
\text { bipunctatus })\end{array}$ \\
\hline $\begin{array}{l}\text { Moisture } \\
\text { content } \\
\text { (weight \%) }\end{array}$ & 76.13 & 66.40 & 75.67 & 72.22 & 76.47 & 75.76 \\
\hline $\begin{array}{l}\text { Nitrogen } \\
\text { content } \\
\text { (weight \%) }\end{array}$ & 2.800 & 3.348 & 2.867 & 3.088 & 2.722 & 2.739 \\
\hline $\begin{array}{l}\text { Protein } \\
\text { content } \\
\text { (weight \%) }\end{array}$ & 17.50 & 20.92 & 17.92 & 19.30 & 17.01 & 17.12 \\
\hline $\begin{array}{l}\text { Fat content } \\
\text { (weight \%) }\end{array}$ & 4.09 & 11.53 & 4.13 & 4.82 & 3.64 & 3.85 \\
\hline $\begin{array}{l}\text { Ash content } \\
\text { (weight \%) }\end{array}$ & 1.02 & 0.82 & 1.41 & 1.78 & 1.92 & 1.96 \\
\hline
\end{tabular}

In our investigation, the highest protein content was found in the tiny carp meat and amounts to $20.92 \%$. The lowest value $(17.01 \%)$ determined for the protein content in the bleak meat. In this paper the content of proteins in the carp meat of $17.50 \%$ was determined, which is in accordance with the values for the protein content $(17.30 \pm 0.39 \%)$ in fillets of the consumable carp from the Ečka fishpond (Ljubojević et al., 2013). The content of proteins in the meat of the tiny carp is $20.92 \%$, which is higher than the value determined by Ljubojević et al. (2013). This fact can be explained by the influence of exogenous factors, such as the age and size of the fish, since the diet has a lesser effect on the protein content of fish meat (Shearer, 1994). The protein content of the rainbow trout meat was $17.92 \%$ and was slightly lower compared to the protein content determined by Bud et al. (2008) - 18.88\% and Celik et al. (2008a) - 19.60\%. The protein content in our investigation in the Prussian carp meat is $19.30 \%$. Lower protein content $(17.99 \pm 0.338 \%)$ in the Prussian carp meat is registered by İzci 
(2010), while similar values (19.43 $\pm 0,21 \%)$ of the protein content were determined by Ozyilmaz et al. (2016). Slightly higher protein content (20.23 \pm $0.31 \%$ ) compared to the results of our work reported by Mahdi et al. (2006). The protein content in the bleak meat is $17.01 \%$, in schneider meat it is $17.12 \%$. Although the values for the protein content in the meat of bleak and the schneider are similar in this work, their values are less than the value $(17.79 \pm 0.08 \%$ and $19.3 \pm 0.1 \%$ ) in the related fish species Alburnus mossulensis (Mahdi et al., 2006; Duman and Peksezer, 2016). Greatest impact on the protein content in fish meat has the species and size, as well as the age and full maturity of the fish.

The highest fat content was found in the tiny carp meat $(11.53 \%)$. The lowest fat content is determined in the bleak meat, which comes from the open waters, amounting to $3.64 \%$. The content of fat in the tiny carp meat was $11.53 \%$, which is higher in relation to the content of fat in carp fillets from the Vrbas pond cage system $(9.79 \pm 0.8 \%)$ (Ljubojević et al., 2013). In our examination, the value for fat content in the carp meat was $4.09 \%$. The content of fats in carp fillets originating from the Ečka fishpond was $3.41 \pm 1.37 \%$ (Ljubojević et al., 2013). The higher content of fat in the tiny carp meat with respect to the contents of the carp can be explained by differences in genetic, intensity and type of diet, age and full maturity, as well as the presumption that the fish species with higher fat content in meat had limited or slowed down movement in conditions of cultivation. The fat content of $4.13 \%$, found in this work in the rainbow trout meat, is higher $(2.94 \%)$ compared to the results of Bud et al. (2008), and similar to the results (4.43\%) determined by Celik et al. (2008). The determined percentage of fats in this work for the Prussian carp meat amounts to $4.82 \%$, which is about the value $(4.63 \pm 0.32 \%)$ stated by İzci $(2010)$. Some lower values for fat content in the prusssian carp meat $(3.43 \pm 0.17 \%$ and $4.07 \pm 0.3 \%$ ) are recorded by Ozyilmaz et al. (2016) and Mahdi et al. (2006). The fat content of $3.64 \%$ in the bleak meat, and $3.85 \%$ in the schneider meat are slightly higher than the value in the related fish species Alburnus mossulensis recorded by other authors $-3.38 \pm 0.25 \%$ (Mahdi et al., 2006) and $1.24 \pm 0.1 \%$ (Duman and Peksezer, 2016). The content of fats in fish meat of species inhabiting open water is considerably lower compared to cultivated species. The quality of nutrition (ratio of individual components and caloric value) is a crucial factor determining the content of fat in fish meat. In addition, the results of this study confirm the results of a large number of researchers that indicate that fish originated from open waters have higher moisture content and lower fat content compared to rearing fish.

The highest value of ash content determined in the schneider meat (1.96\%), while the smallest value for the ash content is determined in the tiny carp meat $(0.82 \%)$. The determined values for the content of ash in the carp and the tiny carp meat are $1.02 \%$ and $0.82 \%$, they do not differ significantly from the value of the ash content in the carp fillets from Ečka fishpond $(1.04 \pm 0.02 \%)$, and in the fillets of carp $(0.88 \pm 1.00 \%)$ from the cage system of the Vrbas fishpond 
(Ljubojević et al., 2013). The ash content in the rainbow trout meat was $1.41 \%$, which is in line with the results of other authors - 1.15\% (Bud et al., 2008) and $1.36 \%$ (Celik et al., 2008). The rainbow trout is inhabited by watercourses with an increased content of limestone and other minerals, which can affect ash values more in comparison with the carp that is grown in standard ponds. In our investigation, the content of ash in the Prussian carp meat is determined at $1.78 \%$. This value is higher than the value $(0.93 \pm 0.03 \%)$ determined by Ozyilmaz et al. (2016), and $0.81 \pm 0.04 \%$ recorded by İzci (2010), and lower than the value $(2.35 \pm 0.19 \%)$ determined by Mahdi et al. (2006). Changes in the content of ash in fish meat are largely due to the nutritional characteristics and the metabolic abilities of fish to accumulate mineral substances (Yesser, 1988). In our examinations, the ash content in the bleak and schneider meat is $1.92 \%$ and $1.96 \%$, respectively. The value for the ash content in the schneider meat is approximately the same for the same parameter $(1.95 \pm 0.16 \%)$, which was determined by a group of authors in related fish species Alburnus mossulens (Mahdi et al., 2006). Duman and Peksezer (2016) found lower ash content in raw meat of this species $(1.00 \pm 0.0 \%)$.

\section{Conclusion}

Most of the chemical composition parameters are very little differs from the values for the same parameters for most of the investigated fish species, which are available in the literature data. The highest moisture content is determined in the bleak meat and amounts to $76.47 \%$, and the lowest moisture content of $66.40 \%$ was recorded in the tiny carp meat. The results of these investigations, as well as a number of other studies, confirm that fish originated from open waters have a generally high content of water and low fat content, while for fish from rearing is characterized by low water content and high fat content. The highest protein content was found in the tiny carp meat $(20.92 \%)$, and the lowest value $(17.01 \%)$ determined for the protein content in the bleak meat. The protein content depends predominantly on the species, body size, age and full maturity of the fish, while it is less affected by the diet. The highest fat content was found in the tiny carp meat $(11.53 \%)$, which is a consequence of genetic characteristics and intensive feeding in fishery conditions. The lowest fat content was determined in the bleak meat, amounting to $3.64 \%$. The highest value of the ash content is determined in the schneider meat, which is $1.96 \%$, the lowest in the tiny carp meat $(0.82 \%)$. Open water fish have higher ash content as a result of life in ecosystems that contain larger amounts of limestone and other minerals. Fish meat is an easily digestible food because of the high content of water, proteins and other nutrients. Approximately $95 \%$ of the nutrients present in fish meat are absorbed (approximately $96 \%$ proteins and $91 \%$ fat). In addition, the energy value of fish meat is almost two times smaller than the meat of warmblooded animals used for human consumption. The use of fish in people's diets is 
on the increase, which is in line with the recommendations of the World Health Organization, which points to the importance of fish meat as an essential component of healthy eating.

\section{Acknowledgments}

This research was supported by the Ministry of Education, Science and Technological Development of the Republic of Serbia, Projects III 46009 and TR 31011 .

\section{References}

A beroumand A. (2010): The effect of water activity of preservation quality of fish, a review. World Journal of Fish and Marine Science, 2 (3): 221-225.

Ackman R.G. (2000): Nutritional composition of fats in seafood. Progress in Food and Nutrition Science, 13: 161-241.

Alasalvar C., Taylor K.D.A., Zubcov E., Shahidi F., Alexis M. (2002): Differentiation of cultured and wild sea bass (Dicentrarchus labrax): total lipid content, fatty acid and trace mineral composition. Food Chemistry, 79: 145-150.

Begum M., Begum M., Shakir uddin Ahmed, Akter T. (2013): Studies on the Effectiveness of Tejpata (Cinnamomum tamala Nee) Leaf Extract on Dried Kachki (Corica soborna) Fish Preservation in Laboratory Condition. American Journal of Food Science and Technology, 1: 14-17.

Bud I., Ladesi D., Reka S.T., Negrea O. (2008): Study concerning chemical composition of fish meat depending on the considered species. Zoorehnie si Biotehnologii, 42 (2): 201-206.

Burger J., Gochfeld M. (2009): Perceptions of the risks and benefits of fish consumption: Individual choices to reduce risk and increase health benefits. Environmental Research, 109: 343-349.

Celik M., Gocke M.A., Basusta N., Kucukgulmez A., Tasbozan O., Tabakogly S.S. (2008): Nutritional quality of rainbow trout (Oncorhynchus mykiss) caught from the Ataturk Dam lake in Turkey. Journal of Muscle Foods, 19 (1), 50-61.

Ćirković M., Zarić B., Jurakić Ž., Ugarčina N., Milošević M., Maletin S. (2005): Proizvodnja konzumnih kategorija riba upotrebom kompletnih krmnih smeša. II Međunarodna konferencija „Ribarstvo”, Institut za stočarstvo Poljoprivrednog fakulteta, Beograd: 42-46.

Đorđević N., Grubić G., Stojanović B. (2005). Proteini u ishrani riba. II Međunarodna konferencija „Ribarstvo”, Institut za stočarstvo Poljoprivrednog fakulteta, Beograd: 264-271.

Duman M., Peksezer B. (2016): Quality changes of fish balls prepared from of mosul bleak (Alburnus mossulensis) stored at $-18{ }^{\circ} \mathrm{C}$ under air or vacuum. Ege Journal of Fisheries and Aquatic Sciences, 33(3): 285-290.

Gandotra R., Sharma S., Koul M., Gupta S . (2012): Effect of Chilling and Freezing on Fish Muscle". IOSR Journal of Pharmacy and Biological Sciences (IOSRJPBS), 2: 5-9. 
Huss H.H. (1995): Quality and quality changes in fresh fish. Food and Agriculture Organization of the United Nations (FAO) fisheries technical paper - 348.

İzci L. (2010): Utilization and Quality of Fish Fingers from Prussian Carp (Carassius gibelio Bloch, 1782). Pakistan Veterinary Journal, 30 (4): 207-210.

Kaushik S.J. (1995): Nutrient requirements, supply and utilization in the contest of carp culture. Aquaculture, 129: 225-241.

Kmínková M., Winterová R., Kučera J. (2001): Fatty acids in lipids of carp (Cyprinus carpio) tissues. Czech Journal of Food Sciences, 19: 177-181.

Konosu, S., Yamaguchi, K. (1982): The flavor components in fish and shellfish. In Martin R.E. et al. (eds.), Chemistry and biochemistry of marine food products, AVI Publishing Co., Westport, Connecticut: 367-404.

Ljubojević D., Ćirković M., Gudžić S., Đorđević V., Trbović D., Vranić D., Novakov N. (2013): Hemijski sastav, sadržaj holesterola i sastav masnih kiselina šarana (Cyprinus carpio) iz slobodnog izlova, poluintenzivnog i kaveznog sistema gajenja, Tehnologija mesa, 54 (1): 48-56.

Love R.M. (1988): The Food Fishes. Their Intrinstic Variations and practical Implications. Van Nostrand Reinhold, New York.

Lovell R.T., Mohammed T. (1989): Content of omega-3 fatty acids can be increased in farm-raised catfish. Highlight of Agricultural Research, Alabama Agricultural Experimental Station, 35: 16-33.

Mahdi A.A., Faddagh M.S., Tuman A.J., Abdullah T.A. (2006): Biochemical composition and calorific value of six fresh water fish species from southern Iraqi Marshes. Marsh Bulletin 1 (1): 47-53.

Ozyilmaz A., Erguden S.A., Erguden D., Özeren A., Semerci R.S.N. (2016): The proximate compositions, carbohydrate contents and energy values of three freshwater fish from Seyhan River in Adana/Turkey. Journal of Entomology and Zoology Studies, 4 (4): 1153-1155.

Shearer K.D. (1994): Factors affecting the proximate composition of cultured fishes with emphasis on salmonids. Aquaculture, 119: 63-88.

Silva J.L., Chamul R.S. (2000): Composition of marine and freshwater finfish and shellfish species and their products. In Martin R.E., Carter E.P., Flick G.J. Jr., Davis L.M. (Eds.), Marine and freshwater products handbook, Technomic Publishing Company, Inc., USA: 31-46.

Stansby M.E., Hall A.S. (1967): Chemical composition of commercially important fish of the USA. Fish. Ind. Res., 3: 29-34.

Sushchik N.N., Gladyshev M.I., Kalachova G.S. (2007): Seasonal dynamic of fatty acid content of a common food fish from the Yenisei river, Siberian grayling, Thymallus arcticus. Food Chemistry, 104, 4: 1353-1358.

Yesser A.K.T. (1988): Seasonal variation in the chemical composition in muscles and gonads of two Iraqi fishes Barbus luteus (Heckel) and B. sharpeyi (Gunther) in relation to their reproductive cycle in Hor AL-Hammar. M.Sc. Thesis, Basrah University, Iraq.

Žlender B. (2000): Morske in slatkovodne ribe. Sestava in kakovost mesa rib. Meso in mesnina, 1 (1): 42-43. 
Acta Agriculturae Serbica, Vol. XXII, 43 (2017); 47-55

\title{
OSNOVNI PARAMETRI KVALITETA SVEŽEG MESA RAZLIČITIH VRSTA SLATKOVODNIH RIBA
}

\author{
Vladimir Kurćubić ${ }^{1}$, Goran Marković ${ }^{1}$, Pavle Mašković ${ }^{1}$, Nemanja Miletić ${ }^{1}$, \\ Dušan Vučićević ${ }^{1}$ \\ ${ }^{1}$ Univerzitet u Kragujevcu, Agronomski fakultet u Čačku, Cara Dušana 34, 32000 \\ Čačak, Republika Srbija
}

\begin{abstract}
Rezime
Cilj istraživanja ovog rada je bio da se uporedi hemijski sastav svežeg mesa različitih vrsta slatkovodnih riba koje se koriste $u$ ishrani potrošača. Pored toga, izvršeno je poređenje osnovnih hemijskih parametara kvaliteta mesa gajenih $\mathrm{i}$ ribljih vrsta iz slobodnog izlova. Najveći broj parametara hemijskog sastava se za većinu ispitivanih ribljih vrsta veoma malo razlikuje od vrednosti za iste parametre, koje su dostupne u podacima iz literature. Rezultati ovog, kao i većeg broja drugih istraživanja, potvrđuju da meso ribe iz slobodnog izlova ima uglavnom visok sadržaj vode i nizak sadržaj masti, dok ribu iz uzgoja karakteristiše nizak sadržaj vode i visok sadržaj masti. Sadržaj proteina je najviši u mesu vrste maloljuskavi šaran i iznosi $20.92 \%$, dok je najniža vrednost zabeležena u mesu uklije (17.01\%). Najviši sadržaj masti utvrđen je u mesu maloljuskavog šarana $(11.53 \%)$, što je posledica genetskih karakteristika i intenzivnog hranjenja u ribnjačkim uslovima. Najniži sadržaj masti je bio u uzorku svežeg mesa uklije i iznosio je 3.64\%. Najviša vrednost sadržaja pepela utvrđena je u mesu vrste dvoprugasta uklija i iznosi $1.96 \%$, najniža u mesu vrste maloljuskavi šaran $(0.82 \%)$. Ribe iz otvorenih voda imaju veći sadržaj pepela što je posledica života u ekosistemima koji sadrže veće količine krečnjaka i drugih minerala.
\end{abstract}

Ključne reči: slatkovodne ribe, sirovo meso, hemijski sastav. 